LPPM UNIHAZ $\quad \begin{gathered}\text { ABDIHAZ: Jurnal Ilmiah Pengabdian pada Masyarakat } \\ \text { https://journals.unihaz.ac.id/index.php/abdihaz }\end{gathered}$

\title{
Pendampingan Kelompok Tani Anugrah Memanfaatkan Eceng Gondok Sebagai Bahan Baku Pakan Ikan Gurame
}

\section{Assistance to Anugrah Farmers Group Utilizing Water Hyacinth as a Raw Material for Carp Feed}

\author{
Saronom Silaban ${ }^{1 *}$, Murniaty Simorangkir ${ }^{1}$, Juniastel Rajagukguk ${ }^{2}$ \\ ${ }^{1}$ Jurusan Kimia, Universitas Negeri Medan, Jl. Willem Iskandar Psr. V Medan Estate, Medan 20221, Indonesia \\ 2 Jurusan Fisika, Universitas Negeri Medan, J1. Willem Iskandar Psr. V Medan Estate, Medan 20221, Indonesia
}

\begin{tabular}{l}
\hline Info Artikel \\
\hline Diterima 02 Desember 2021 \\
Ditelaah 09 Desember 2021 \\
Disetujui 27 Desember 2021 \\
Tersedia daring 30 Desember \\
2021 \\
*Penulis untuk korespondensi \\
saronomsilaban@unimed.ac.id \\
\hline \\
Kata Kunci: \\
Eceng gondok, Pakan organik, \\
Ikan gurame
\end{tabular}

Keywords:

Water hyacinth, Organic feed, Gurame fish

\begin{tabular}{l} 
ABSTRAK \\
\hline Eceng gondok (Eichornia crassipes) selain merugikan juga dapat \\
menguntungkan karena dapat digunakan sebagai pakan ternak, pakan ikan, \\
pupuk organik, dan pembuatan biogas daft penjernihan air. Enceng gondok \\
seperti halnya tanaman lain mengandung protein yang dibutuhkan oleh ikan \\
Gurame (Osphronemus gouramy Lac). Tujuan kegiatan program kemitraan \\
masyarakat ini adalah melakukan pendampingan terhadap mitra dalam \\
memanfaatkan eceng gondok sebagai bahan baku pakan ikan gurame. \\
Pendekatan yang dilakukan adalah dengan metode perencanaan, pelatihan dan \\
pendampingan. Hasil kegiatan kemitraan masyarakat menunjukkan bahwa \\
mitra telah memiliki pengetahuan dalam mengolah eceng gondok sebagai \\
bahan baku pakan ikan, dapat menekan biaya produksi yang tinggi. \\
Perbandingan harga pakan komersial dan pakan berbahan eceng gondok yakni \\
Rp.12.000,- berbanding Rp.6.058,- dan mempercepat pertumbuhan ikan \\
gurame.
\end{tabular}

\section{ABSTRACT}

Water hyacinth (Eichornia crassipes) is not only harmful but also beneficial because it can be used as animal fodder, fish fodder, organic fertilizer, and biogas production and water purification. Water hyacinth like other plants contains protein needed by carp (Osphronemus gouramy Lac). The purpose of this community service activity is to provide assistance to partners in utilizing water hyacinth as a raw material for carp feed. The approach taken is the methods namely planning, training and mentoring. The results of the community service activity show that partners already have knowledge in processing water hyacinth as a raw material for fish feed, which can reduce high production costs. Comparison of the price of commercial animal feed and animal feed made from water hyacinth is 12,000 IDR compared to 6,058 IDR and can accelerate the growth of carp.

ISSN 2685-0354 (Media Online). Diterbitkan oleh Universitas Prof. Dr. Hazairin, SH. Ini merupakan jurnal bebas akses di bawah lisensi Creative Commons Atribution 4.0 International.

\section{PENDAHULUAN}

Ikan gurame telah menjadi primadona sebagai ikan budidaya oleh petani ikan di Indonesia, juga di desa Besar Martubung. Namun dalam budidaya ikan ini masih terdapat permasalahan, seperti pertumbuhannya yang lambat bila dibandingkan dengan ikan budidaya lainnya. Hal ini 
diduga karena ikan gurame mengalami defisiensi nutrien dalam makananya (Suprayudi \& Setiawati, 2003), sehingga diperlukan pakan berkualitas baik dalam iumlah yang cukup (Mokoginta et al., 1995).

Pakan merupakan salah satu aspek penting yang harus diperhatikan dalam kegiatan budidaya, sebab pakan merupakan sumber energi untuk menunjang pertumbuhan. Pakan yang baik adalah pakan yang sesuai dengan kebutuhan fisiologi dan spesies ikan yang dibudidayakan (Silaban et al., 2021). Pemberian pakan dengan kualitas dan kuantitas yang baik dapat mengoptimalkan usaha budidaya ikan. Pakan harus tersedia dalam jumlah yang cukup, diberikan pada waktu yang tepat, dan mempunyai kandungan gizi yang dibutuhkan untuk pertumbuhan ikan (Juliana et al., 2018). Tingginya harga pakan berbahan kimia menjadi kendala dalam pemenuhan nutrient pakan untuk pertumbuhan ikan gurame. Salah satu nutrien penting yang dibutuhkan ikan gurame adalah protein. Kebutuhan protein untuk ikan gurame ukuran 0,15-0,18 gram per ekor sebesar 43,29\%, sedangkan untuk ukuran 27-35 gram per ekor dibutuhkan kadar protein sebesar 32,14\% (Syaputra et al., 2018). Tingginya biaya pakan juga dapat menyebabkan penurunan produksi petani ikan. Salah satu upaya menanggulangi permasalahan tersebut adalah mencari alternatif bahan pakan murah, ekonomis dan mengandung kebutuhan gizi untuk pertumbuhan ikan.

Eceng gondok adalah tumbuhan yang dapat diolah menjadi pakan alternatif (organik) ikan gurame yang berprotein dan bernutrisi tinggi yang sangat cocok untuk pertumbuhan ikan gurame. Pakan alternatif ikan gurame berbahan eceng gondok ini sangat murah dan ekonomis (Jafari, 2010) karena bahan bakunya banyak dan mudah diolah menjadi pakan. Eceng gondok sangan cocok digunakan sebagai pakan ikan (Muchtaromah et al., 2006; Fitrihidajati et al., 2015). Eceng gondok memang sangat potensial untuk pakan ikan, karena kandungan protein-nya yang tinggi $(11,2 \%)$ (Fitrihidajati et al., 2015). Penelitian lain melaporkan bahwa eceng gondok yang selama ini dikenal sebagai gulma air yang mengganggu dan sulit dibasmi ternyata dari beberapa penelitian diketahui mempunyai kandungan protein yang cukup tinggi yaitu antara 12-18 \% serta kandungan asam amino cukup lengkap (Lttle, 1979; Muchtaromah et al., 2006).

Kelompok ternak ikan "Anugrah" merupakan usaha mikro ternak ikan gurame yang menjual ikan gurame komsumsi ke pasar-pasar tradisional di kota Medan. Tingginya permintaan ikan gurame ini belum memberikan keuntungan yang maksimal bagi kelompok mitra. Hal ini disebabkan tingginya harga pakan (pellet) yang membuat biaya produksi ternak ikan gurame cukup tinggi, karena sekitar $60-70 \%$ biaya produksi itu digunakan untuk pembelian pakan (Pamungkas, 2012; Putra et al., 2020). Tingginya biaya produksi ini membuat keuntungan mitra menjadi relatif rendah. Jika kelompok mitra dapat membuat sendiri pakan organik ikan tanpa mengurangi nilai nutrisinya dari bahan baku yang cukup tersedia di lokasi mitra tentu dapat mengurangi biaya produksi sehingga dapat meningkatkan keuntungan mitra. Ketersedian tumbuhan eceng gondok yang melimpah dan dapat menyebabkan pendangkalan air merupakan suatu pertimbangan bagi mitra untuk membuat sendiri pakan ikan. Kegiatan program kemitraan masyarakat ini bertujuan untuk melakukan pendampingan terhadap mitra dalam memanfaatkan eceng gondok sebagai bahan baku pakan ikan gurame.

\section{METODE}

Metode pelaksanaan kegiatan kemitraan masyarakat yang ditawarkan untuk mengatasi permasalahan yang dihadapi mitra adalah melalui pendekatan P3, yaitu perencanan, pelatihan dan pendampingan (Silaban et al., 2021). 
Tahap Perencanaan. Pada tahap ini dilakukan perencanaan yang matang terkait pelaksanaan program kemitraan masyarakat (PKM) ini agar dapat berjalan dengan lancar. Pada tahap ini dilakukan koordinasi tim pelaksana dengan pihak Lembaga Penelitian dan Pengabdian pada Masyarakat Universitas Negeri Medan terkait izin kegiatan dan kelompok mitra, serta pihak pemerintah setempat. Dilakukan persiapan bahan-bahan dan peralatan penunjang yang diperlukan untuk menjamin kelancaran pelaksanaan PKM tersebut. Pada tahap perencanaan ini juga disiapkan bahan pelatihan yang akan diberikan oleh tim pelaksana saat tahap pelatihan.

Tahap Pelatihan. Tahap pelatihan dilakukan dengan menghadirkan ketiga tim pelaksana PKM, yaitu Dr. Saronom Silaban, Dr. Murniaty Simorangkir, dan Dr. Juniastel Rajagukguk sebagai narasumber. Pelatihan ini difokuskan pada pemberian pengetahuan, motivasi dan cara pembuatan bahan baku pakan ikan gurame dari eceng gondok. Pelatihan kepada mitra dilaksanakan di lokasi mitra (Gambar 1). Pada tahap pelatihan dijelaskan standar operasional prosedur (SOP) pengolahan eceng gondok menjadi bahan baku pakan ikan organik, yaitu (1) pengumpulan; (2) pencacahan; (3) pengeringan; (4) penepungan; dan (5) pencapuran formulasi pellet. Formulasi pakan ikan gurame berbasis bahan baku eceng gondok untuk $100 \mathrm{~kg}$ Pelet (Tabel 1).

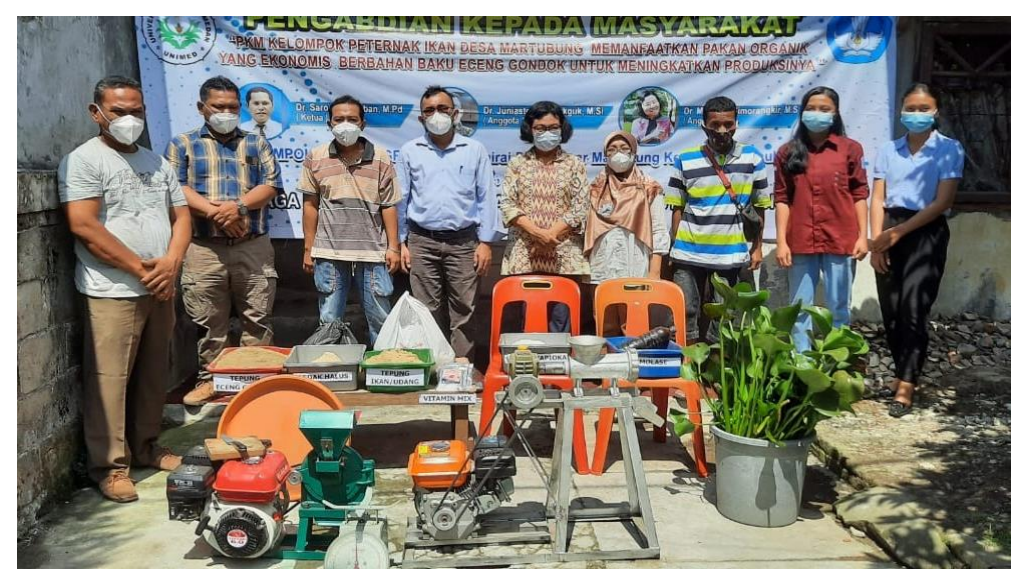

Gambar 1. Pembukaan kegiatan PKM di lokasi mitra.

Tabel 1 Formulasi pakan ikan gurame berbahan baku eceng gondok

\begin{tabular}{llc}
\hline No & Komponen & Takaran \\
\hline 1 & Tepung Eceng Gondok & $30,0 \mathrm{~kg}$ \\
2 & Tepung Ikan & $40,0 \mathrm{~kg}$ \\
3 & Dedak Halus & $15,0 \mathrm{~kg}$ \\
4 & Tepung Tapioka & $13,0 \mathrm{~kg}$ \\
5 & Vitamin Mix & $1,0 \mathrm{~kg}$ \\
6 & Molase/Minyak Ikan & $1,0 \mathrm{~kg}$ \\
\hline \multicolumn{2}{l}{ Total } & $100 \mathrm{~kg}$ \\
\hline
\end{tabular}

Tahap Pendampingan. Tahap ini difokuskan pada kegiatan pendampingan mitra oleh tim pelaksana untuk memastikan bahwa semua kegiatan PKM berjalan sesuai dengan rencana awal yang telah disepakati. Pendampingan dilakukan oleh tim pelaksana sehingga semua tahapan kegiatan dalam mengolah pakan ikan gurame berbahan eceng gondok benar-benar dilaksanakan oleh mitra. Selain itu, tim pelaksana harus memastikan bahwa mitra telah dapat melakukan proses 
atau tahap demi tahap pengolahan eceng gondok menjadi pakan ikan gurame, serta memastikan bahwa pemberian pakan berbahan eceng gondok dapat mempercepat pertumbuhan ikan gurame dan menekan biaya produksi yang tinggi.

\section{HASIL DAN PEMBAHASAN}

Pelaksanaan Pelatihan dan Pendampingan Program Kemitraan Masyarakat. Program Kemitraan Masyarakat (PKM) dilakukan setidaknya 3 kali kunjungan lapangan yang meliputi: kegiatan pelatihan pengolahan eceng gondok menjadi pakan organik ikan gurame bernutrisi tinggi, transfer teknologi pengolahan eceng gondok kepada mitra, dan kegiatan pendampingan (Tabel 2).

Tabel 2 Pelaksanaan kegiatan Program Kemitraan Masyarakat di lokasi mitra kelompok peternak ikan "Anugrah" di desa Besar Martubung

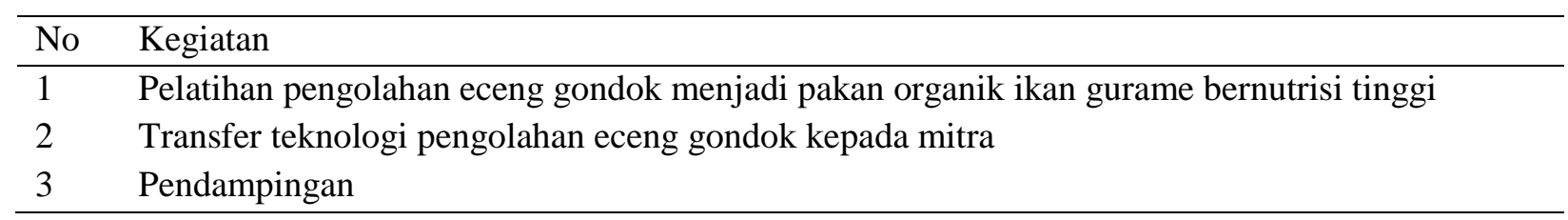

Kegiatan PKM oleh tim pelaksana (Dr. Saronom Silaban, Dr. Juniastel Rajagukguk, dan Dr. Murniaty Simorangkir) telah dilaksanakan dengan mitra kelompok tani ikan "Anugrah" yang fokus usahanya budidaya ikan Gurame. Kelompok mitra ini diketuai oleh Bpk. Anugrah Haris Simangunsong yang beralamat di Jl. Tempirai Desa Besar Martubung, Kecamatan Medan Labuhan. Kegiatan selanjutnya adalah memberikan pelatihan kepada kelompok mitra terkait pengolahan eceng gondok menjadi pakan organik ikan gurame bernutrisi tinggi, transfer teknologi pengolahan eceng gondok kepada mitra, dan kegiatan pendampingan (Gambar 2a dan 2b).

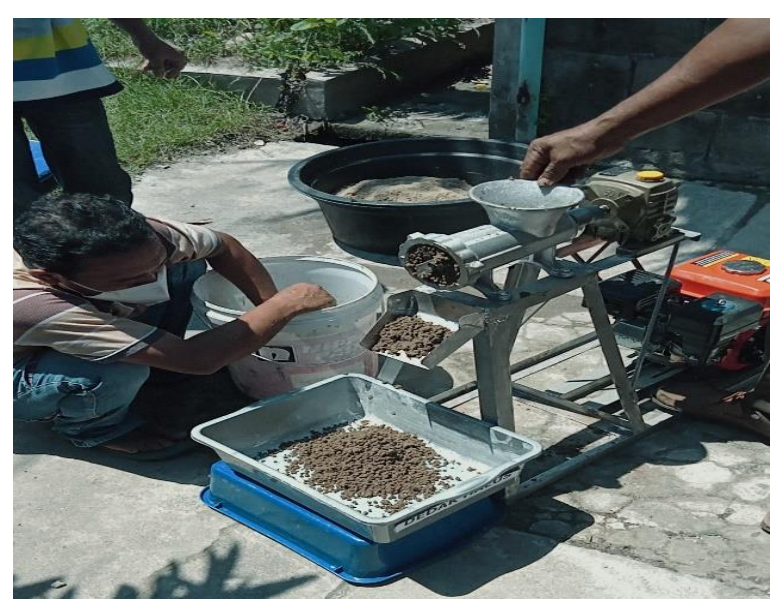

a

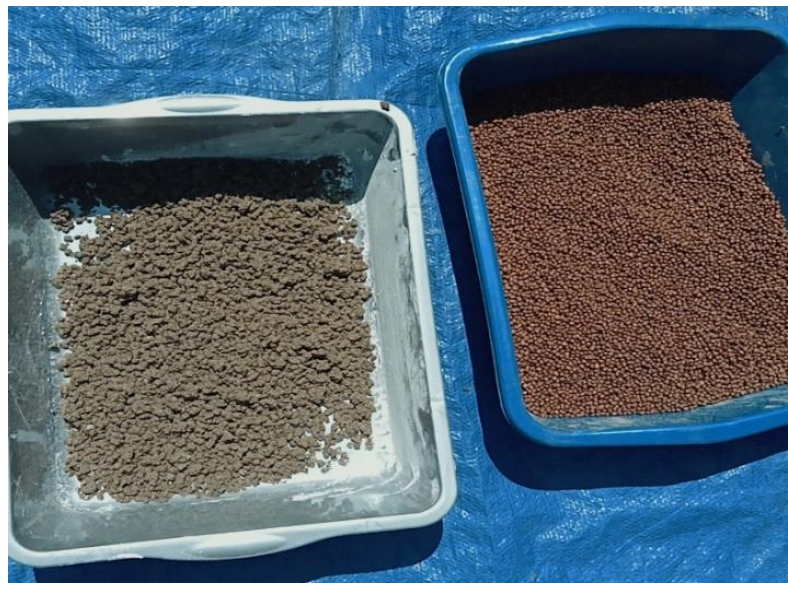

b

Gambar 2. Pendampingan mitra. a. Pencetakan pakan berbahan eceng gondok; b. Produk pakan organik berbahan dasar eceng gondok.

Dampak Ekonomi dan Sosial Pelaksanaan Program Kemitraan Masyarakat. Dampak ekonomi pelaksanaan Program Kemitraan Masyarakat ini bagi kelompok mitra adalah pertumbuhan ikan gurame yang meningkat paska pemberian pakan organik berbahan baku eceng gondok dibanding pertumbuhan ikan gurame menggunakan pakan ikan dari sayur-sayuran. Sebelumnya pertubuhan ikan gurame hanya disekitar 20 gram per bulannya, kini meningkat sekitar 12 gram per bulan menjadi 32 gram per bulan (Tabel 3). 
Peningkatan pertumbuhan ikan gurame paska pemberian pakan organik berbahan baku eceng gondok ini sangat menguntungkan bagi mitra. Tingginya biaya produksi menggunakan pakan yang dibeli dari pasaran dapat ditekan dengan menggunakan pakan buatan ini. Hal ini tentu sangat menguntungkan secara ekonomi bagi mitra kelompok tani ikan "Anugrah" (Tabel 4).

Tabel 3 Perbandingan pertumbuhan ikan gurame yang diberi pakan organik berbahan baku eceng gondok dengan pakan dari sayur-sayuran.

\begin{tabular}{llll}
\hline Indikator & $\begin{array}{l}\text { Pakan organik berbahan } \\
\text { baku eceng gondok }\end{array}$ & Pakan sayur-sayuran & Peningkatan \\
\hline $\begin{array}{l}\text { Pertumbuhan Ikan } \\
\text { Gurame }\end{array}$ & $32 \mathrm{~g} /$ bulan & $20 \mathrm{~g} / \mathrm{bulan}$ & $12 \mathrm{~g} / \mathrm{bulan}$ \\
\hline
\end{tabular}

Tabel 4 Perbandingan biaya pakan ikan dari pasaran dengan pakan organik berbahan eceng gondok

\begin{tabular}{ll}
\hline Pakan dari pasaran per kg & Pakan berbahan dasar eceng gondok per kg \\
\hline 12.000 & 6.058 \\
\hline
\end{tabular}

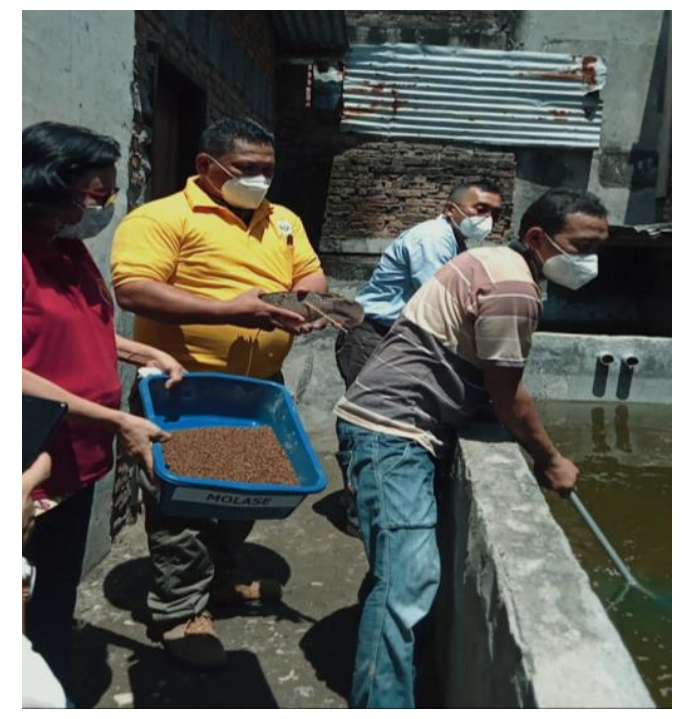

Gambar 4 Hasil panen ikan pasca pemberian pakan organik berbahan dasar eceng gondok.

Dampak sosial pelaksanaan PKM ini adalah meningkatnya pendapatan mitra secara ekonomi, maka akan merangsang munculnya pengusaha-pengusaha baru khususnya yang bergerak di bidang budidaya dan peternakan ikan gurame. Dampak lain pelaksanaan kegiatan PKM ini adalah meningkatnya kemampuan masyarakat khususnya kelompok mitra dalam memanfaatkan bahan baku lokal hama keong mas menjadi bahan yang sangat bermanfaat secara ekonomi, seperti pakan ikan organik. Selain itu, adanya transfer ilmu pengetahuan dan teknologi tepat guna bagi masyarakat untuk dapat mengolah bahan-bahan yang dianggap tidak bermanfaat menjadi bahan yang sangat bermanfaat untuk kesejahteraan masyarakat pada umumnya. Hasil panen ikan pasca pemberian pakan organik berbahan keong mas ditunjukkan pada Gambar 4.

\section{KESIMPULAN}

Pelaksanaan kegiatan program kemitraan masyarakat memanfaatkan eceng gondok sebagai bahan baku pakan organik ikan gurame dapat menekan tingginya biaya produksi, mempercepat 
pertumbuhan ikan gurame. Hasil kegiatan PKM ini juga dapat meningkatkan kemampuan (skill) mitra terutama dalam mengolah eceng gondok menjadi pakan organik untuk ikan gurame.

\section{UCAPAN TERIMA KASIH}

Ucapan terimakasih disampaikan kepada Direktorat Riset dan Pengabdian kepada Masyarakat Deputi Bidang Penguatan Riset dan Pengembangan Kementerian Riset dan Teknologi/Badan Riset dan Inovasi Nasional sesuai dengan Kontrak Pelaksanaan Program Pengabdian kepada Masyarakat Nomor: 60/SP2H/PPM/DRPM/2021.

\section{DAFTAR PUSTAKA}

Fitrihidajati, H., Ratnasari, E., \& Soeparno, G. (2015). Kualitas hasil fermentasi pada pembuatan pakan ternak ruminansia berbahan baku eceng gondok (Eichornia crassipes). Biosaintifika: Journal of Biology \& Biology Education, 7(1), 62-67. DOI: https://doi.org/10.15294/biosaintifika.v7i1.3540

Jafari, N. (2010). Ecological and socio-economic utilization of water hyacinth (Eichhornia crassipes Mart Solms). Journal of Applied Sciences and Environmental Management, 14(2) 43- 49. DOI: https://doi.org/10.4314/jasem.v14i2.57834

Juliana, J., Koniyo, Y., \& Panigoro, C. (2018). Pengaruh pemberian pakan buatan menggunakan limbah kepala udang terhadap laju pertumbuhan dan kelangsungan hidup benih ikan gurame (Osphronemus gouramy). Jurnal Ilmu Kelautan Kepulauan, 1(1), 30-39. DOI: https://doi.org/10.33387/jikk.v1i1.679

Little, E. C. S. (1979). Handbook of utilizationof acquatic plants food and agriculture organization of the nation. Rome.

Mokoginta, I., Suprayudi, M. A., \& Setiawati, M. (1995). Kebutuhan optimum protein dan energi pakan benih ikan gurame (Asphronemus gouramy LAc). Jurnal Penelitian Perikanan Indonesia, 1(3), 82-94.

Muchtaromah, B., Susilowati, R., \& Kusumastuti, A. (2006). Pemanfaatan tepung hasil fermentasi eceng gondok (Eichornia crassipes) sebagai campuran pakan ikan untuk meningkatkan berat badan dan daya cerna protein ikan nila merah (Oreochormis sp.). El-Qudwah, 10, 110.

Pamungkas, W. (2012). Penggunaan enzim cairan rumen sebagai alternatif untuk mendukung pemanfaatan bahan baku pakan ikan lokal. Media Akuakultur, 7(1), 32-38. DOI: http://dx.doi.org/10.15578/ma.7.1.2012.32-38

Putra, A. N., Ristiani, S., Musfiroh, M., \& Syamsunarno, M. B. (2020). Pemanfaatan eceng gondok (Eichornia crassipes) sebagai pakan ikan nila: efek terhadap pertumbuhan dan kecernaan pakan. Leuit (Journal of Local Food Security), 1(2), 77-82. DOI: http://dx.doi.org/10.37818/leuit.v1i2.10016

Silaban, S., Rajagukguk, J., \& Simorangkir, M. (2021). Pendampingan kelompok tani manise memanfaatkan hama keong mas (Pomacea sp) sebagai pakan ikan gurame (Osphronemus gouramy). Jurnal ABDINUS: Jurnal Pengabdian Nusantara, 4(2), 311-320. DOI: https://doi.org/10.29407/ja.v4i2.14740

Suprayudi, M. A., \& Setiawati, M. (2003). Dietary phosphorus requirement of giant gouramy (Osphronemus gouramy Lac.). Jurnal Akuakultur Indonesia, 2(2), 67-71.

Syaputra, R., Santoso, L. S., \& Tarsim, T. (2018). Pengaruh Penambahan tepung daun gamal 
Saronom Silaban et al. Abdihaz: Jurnal Pengabdian pada Masyarakat. 3(2): 80-86

(Gliricidia sepium) pada Pakan buatan terhadap sintasan dan pertumbuhan ikan gurami (Osphronemus gouramy). Jurnal Sains Teknologi Akuakultur, 2(1), 1-11. 